\title{
Male And Female Influence On Hypermarket Brand Equity
}

Hui-Chu Chen, TransWorld Institute of Technology, Taiwan, R.O.C. Robert D. Green, Lynn University, USA

James Miller, Lynn University, USA

\begin{abstract}
Based on the customer-based brand equity theory (Keller, 1993) and its retail construct measures of brand loyalty, brand awareness, perceived quality, and brand association (Pappu, Quester, and Cooksey, 2006), gender differences are presented, tested and analyzed. The study finds that females have significantly higher brand association $(p<0.01)$ and total brand equity $(p<0.05)$. This article concludes with the implications and research opportunities for branding scholars and to consumer product manufacturers and retailers.
\end{abstract}

Keywords: Customer-based brand equity; consumer behavior; gender

\section{INTRODUCTION}

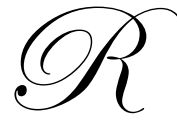

etailing has changed dramatically since World War II. The variety stores and department stores as the dominate format have seen threatening competition from "big box", e.g., hypermarket, stores. This occurrence, at least in part, can be explained by the wheel of retailing (McNair, 1958; Hollander, 1960). McNair (1958) states that types of retailers enter markets with low-price, low-margin format. As these retailers prosper, they have larger and more elaborate facilities, leaving behind their more frugal perception and offerings. Eventually, the retailers evolve to a high-price, higher margin stores. Hollander challenged the wheel of retailing by concluding, "( $t$ )he number of nonconforming examples suggest that the wheel hypothesis is not valid for all retailing" (1960, p. 41). Thirty years later, Brown stated that "the wheel does not need to be changed, nor does it require retreading, rebalancing, or realignment. In my opinion, it needs to be road-tested more often" (1990, p. 147).

Environmental condition changes influence the development of (the wheel of) retailing, e.g., economic, technology, demographic, social factors (McNair and May, 1978). McNair and May (1978) identify important trends as the (1) acceleration of socio-economic change, (2) increase of mass distribution, and (3) rise in consumer influence on retail change. As an example, during the timeframe of the wheel of retailing Wal-Mart has evolved from a small general store in Rogers, Arkansas in 1962 to the world's largest retailer with revenues of \$344 billion, with 6,500 stores and 1.9 million employees in 15 international countries in 2007 (Wal-Mart, 2008). Much of this success at the beginning, and remains today, is that Wal-Mart has an "understanding of what consumers want from a retailer" (Wal-Mart, 2008).

Customers' influence on retail change (McNair and May, 1978) is supported by Wal-Mart's understanding of what consumers want. As a general merchandise retailer, Wal-Mart clearly offers convenience (mass distribution), e.g., one stop shopping, and competitive pricing (consumer influence), e.g., everyday low price. Particular factors (socio-economic) influence consumers shopping and preference. Brokaw (2007) and Penn (2007) have identified and discussed such changes. The traditional family and family members' role have changed significantly in the past 50 years. Today, different than the 1950s and even the 1960s, both spouses work and have their own careers, some even geographically apart from the other. Today, husbands shop for food and clothing while wives purchase durable goods, automobiles and other major (high priced) products. Single parenting has increased greatly. Households have more non-married couples with shared living arrangements with the opposite or same gender. Men and women are waiting longer to marry. People, in general, have many more varied interests and 
activities in additional to work that lead to busy, hectic schedules. Socio-economic factors have, and do influence who and where they shop and what is purchased.

Since World War II branding has moved from a concept to become a significant strategy, particularly for consumer products. However, brand equity is the value placed on products (Aaker, 1991) and from a customer perspective (Keller, 1993). More recently, and specific to this study is measuring retail brand equity (Pappu, Quester, and Cooksey, 2005). Retailer brand equity, and the nontraditional household and buyer provide an opportunity to better understand these trends. $\mathrm{Al}$ and Laura Ries best explain the importance of gender branding in a highly competitive, "big box" retail market, as they state,

Home Depot appeals to men; Lowe's appeal to women. Home Depot is huge, crowded, dark, and dingy; Lowe's is large with wide aisles, neat shelves, and bright lights. Lowe's is a good example of a brilliant No. 2 brand strategy. Be opposite. (2004, p. 192)

Of note, Home Depot has recognized these competitive differences too. In late 2007, Home Depot Design Centers opened in Charlotte, North Carolina and Concord, California (Waters, 2007). The Design Centers are hybrids of Home Depot and its up-scale design Expo stores, and targets female shoppers. The lighting is softer; Home Depot orange has changed to earth tones and neutral color shades; and racks and pallets are replaced with more open layouts and showrooms, e.g., furniture, appliances. Apparently, Lowe's may not be so opposite.

The purpose of this paper is to conceptualize gender role in contributing to brand equity. The objective is to identify in the literature the relationship between gender (male, female) and retail brand equity (brand loyalty, brand awareness, perceived quality, brand association). This study is guided by a quest to answer the question, are there significant differences between gender perceptions of retail stores that influence greater brand equity?

\section{BRAND EQUITY}

While brand equity is difficult and challenging to measure, a few independent organizations have estimated such brand value. Interbrand has valued and ranked firm and product brands for over two decades by certain criteria. For example, more than $30 \%$ of the firm's earnings must be from outside its home country. This eliminates many brands, e.g., Wal-Mart, Home Depot. In addition, parent companies are not included, e.g., Procter \& Gamble, but its brands may be included, e.g., Gillette. Based on such parameters, leading international brands for 2006 included Coca-Cola (at \#1 with US\$67 billion), Microsoft (\#2, US\$56.9 billion), Nokia (\#6, US\$30.1 billion), McDonald's (\#9, US\$27.5 billion), Gillette (\#16, US\$19.5 billion), IKEA (\#41, US\$8.7 billion), Levi’s (\#100, US\$2.6 billion) (The 100 Top Brands, 2006). The following presents the theoretical and empirical basis for the study, the findings, discussion, and concludes with the implications of gender branding.

\section{Theoretical Framework}

Brand equity is defined as "a set of brand assets and liabilities linked to a brand, its name and symbol, that add to or subtract from the value provided by a product or service to a firm and/or to that firm's customers" (Aaker, 1991, p. 15). Aaker (1991) identifies five dimensions of brand equity that includes brand loyalty, brand awareness, perceived quality, brand association, and other propriety brand assets. Brand equity has been studied for two purposes: (1) financial value for merger, acquisition, or divestment and (2) improve marketing strategy and productivity (Keller, 1993). Aaker's brand equity theory was further developed to a consumer's perspective. Keller defined customer-based brand equity "as the differential effect of brand knowledge on consumer response to the marketing of the brand" (1993, p. 2). This brand knowledge includes brand awareness (brand recall and recognition) and brand image (types, favorability, strength, and uniqueness of brand associations). Keller concludes that "consumer-based brand equity occurs when the customer is aware of the brand and holds some favorable, strong, and unique brand associations in memory" (1993, p. 17). Furthermore, branding and brand management are applicable to retail brands, e.g., retail and store image, perceived retail brand association, as well as to retail brand equity measurement (Ailawadi and Keller, 2004). For this study, the customer is either a male or female retail shopper. 


\section{Empirical Evidence}

In an early study of customer-based brand equity (CBBE) measurement, Lassar, Mittal, and Sharma (1995) identified five constructs. These were performance, social image, value, trustworthiness, and attachment. Yoo, Donthu, and Lee (2000) collapsed and refocused these five, and used three measures to test CBBE. The researchers measured perceived quality, brand loyalty and brand awareness/association in a three product (athletic shoes, camera film and television sets) study. However, Pappu, Quester, and Cooksey $(2005 ; 2006)$ questioned, and tested the combining of brand awareness and brand association. First, they (2005) used two products (cars and television sets), and then for retailer CBBE $(2006)$. Both $(2005 ; 2006)$ studies successfully tested CBBE. This retailer CBBE study will use the four construct measures of: (1) brand loyalty, (2) brand awareness, (3) perceived quality, and (4) brand association (Pappu, Quester, and Cooksey, 2006) and for hypermarket retailers.

\section{Brand Loyalty}

From a consumer and purchase perspective, Oliver defines loyalty as "a deeply held commitment to rebuy or repatronize a preferred product/service consistently in the future, thereby causing repetitive same-brand or same brand-set purchasing, despite situational influences and marketing efforts having the potential to cause switching behavior" (1999, p. 34). Loyalty plays an important market and financial performance role in which brand loyalty is directly related to market share and brand price (Chaudhuri and Holbrook, 2001). While empirical studies are somewhat limited and with mixed results, Moutinho and Goode (1995) did find that males were more brand loyal when purchasing automobiles. However, this brand loyalty may depend on product performance or the sales process. In a survey of German car manufacturer customers, males were found to have stronger repurchase intentions based on product satisfaction (product performance) while female intentions were based on personal interaction experience (service performance) (Homburg and Giering, 2001). Furthermore, in a longitudinal study, men had a higher consistency over time with their satisfaction responses, an indicator of loyalty, but women experienced higher dissatisfaction responses (Bendall-Lyon and Powers, 2002).

Based on this review, specifically Oliver's definition of loyalty, e.g., “...... to rebuy or repatronize a preferred product/service consistently in the future ...... despite situational influences and marketing efforts ......." (1999, p. 34), the first hypothesis is that:

$\mathbf{H}_{1}$ : $\quad$ Males have higher brand loyalty.

\section{Brand Awareness}

Brand awareness is the "customers' ability to recall and recognize the brand, as reflected by their ability to identify the brand under different conditions ....... linking the brand - the brand name, logo, symbol, and so forth to certain associations in memory" (Keller, 2003, p. 76). Those conditions can be explained for retailers. Recall becomes important when consumers are out of the retail store and relying on (internal) memory to generate information while recognition is important in the store with thousands of stock keeping units (SKUs) and other instore information for reminding shoppers (external memory) (Bettman, 1979; Solomon, 2007).

Perhaps the best framework to analyze, evaluate, and understand gender brand awareness is the Selectivity Model (Meyers-Levy, 1989). According to the Model, males and females process information, e.g., advertising messages, differently. While males use selective information processing that is heuristic and schematic, females use more comprehensive processing that is an effortful, detailed elaboration. The Selectivity Model, also, acknowledges male-female processing differences are eliminated in different conditions (situations). Meyers-Levy and Maheswaran (1991) found that females used greater detailed elaboration of information than males. However, this difference disappeared when recognition versus recall tasks (condition, situation factors) and/or cue incongruity (information factors) stimulated both genders. Studies have continued to support the Selectivity Model (Darley and Smith, 1995; Walsh and Mitchell, 2005; Handlin, 2007). 
The Selectivity Model identifies differences between males (schematic) and females (elaboration) and the varying levels between genders of recognition and recall that influences brand awareness. The second hypothesis is that:

$\mathbf{H}_{2}$ : $\quad$ Females have higher brand awareness.

\section{Perceived Quality}

Perceived quality is the "customer's judgment about a product's overall excellence or superiority ....... (that) is (1) different from objective or actual quality, (2) a higher level abstraction rather than a specific attribute of a product, (3) a global assessment that in some cases resembles attitude, and (4) a judgment usually made within a consumer's evoked set" (Zeithaml, 1988, pp. 3 and 4). Therefore, a consumer's perceived quality, and the resulting purchase decision may be influenced by "personal product (service) experiences, unique needs, and consumption situations" (Yoo et al., 2000, p. 197).

Positive (Negative) disconfirmation is a function of expectations in which these expectations, e.g., satisfaction, perceived quality, is confirmed or disconfirmed that leads to (no) purchase intention (Oliver, 1980). Expectancy disconfirmation has been a basis of other perceptions, e.g., service gap (Zeithaml, Bittner, and Gremler, 2006). In determining expectations - perceptions - intended behavior, a relationship was found in which "quality is directly influenced only by perceptions" (Boulding, Kalra, Staelin, and Zeithaml, 1993, p. 24). Expectancy, e.g., quality, may be based on a prior experience or if there has not been a prior experience, then on cues. Consumers use cues to infer or to determine perceived (by customers' subjective judgment of) quality. Cues may be a(n) brand (store) name, price (Lichtenstein and Burton, 1989; Rao and Monroe, 1989), and/or advertising (Kirmani and Wright, 1989). Furthermore, cues have greater influence, impact on females. Meyers-Levy and Sternthal found that "women often have a lower threshold for elaborating on message cues, and hence at times may have greater access to the implications of those cues at judgment" (1991, p. 93).

Therefore, the third hypothesis is that:

$\mathbf{H}_{3}$ : $\quad$ Females perceive higher quality.

\section{Brand Association}

Brand association "consists of all brand-related thoughts, feelings, perceptions, images, experiences, beliefs, attitudes," (Kotler and Keller, 2006, p. 188) and "is anything 'linked' in memory to a brand" (Aaker, 1991, p. 109). Such associations may include (brand) personality (Aaker, 1997) and relationships (Fournier, 1998) with inference to gender.

Brand personality influences consumers' brand association and preference. In developing the Brand Personality Scale, Aaker (1997) found two levels of symbolic use of brands. The first level relates to the actual self that includes sincerity (e.g., down-to-earth, honest, wholesome), excitement (e.g., daring, spirited, imaginative), and competence (e.g., reliable, intelligent, successful). The second level relates more to the ideal self of sophistication (e.g., upper class, charming) and ruggedness (e.g., outdoorsy, tough). Her findings indicate that brand personality information uses heuristic cues and may need systematic processing. Based on the Selectivity Model (Meyers-Levy, 1989), males (having heuristic, schematic information processing) will have greater brand association.

Relationships are (1) reciprocal exchanges, (2) purposive, (3) multiplex phenomena, and (4) process phenomena (Fournier, 1998). As applicable to branding, this is not a product or marketing transaction but rather an active, contributing dyad based on quality, depth and strength of the consumer-brand relationship. Fournier observes that "(s)ince women in relationships feel empowered, they emerge as key agents of social change through their dealings in the ordinary world of brand consumption" (1998, p. 367). 
Logically consumers associate brand names that are congruent, e.g., fit, obvious, meaningful (Lutz and Lutz, 1977). Brand congruency would indicate that males, as systematic information processors (Meyers-Levy, 1989), would have higher brand association. However, more recent studies have found differently. For example, moderately incongruent brand names were favored by females as compared to congruent and extreme incongruent brand names (Meyers-Levy, Louie and Curren, 1989). This supports the Selectivity Model (Meyers-Levy, 1989) and favors female consumers who use comprehensive, effortful, detailed information processing.

While brand association studies have mixed results, the fourth hypothesis is:

$\mathbf{H}_{4}: \quad$ Females have higher brand association.

\section{METHODOLOGY}

For the last 60 years retailers have evolved dramatically. Some being highly specialty retailers, others being mega-retailers. The "big box" stores may be hypermarkets (Arnold and Luthra, 2000) that have mass appeal with more than 225,000 square feet of floor space and over 45,000 stockkeeping units (SKUs) (Price and Ferrell, 2007). Some may be perceived as more "female friendly", e.g., Lowe's, while others more "male friendly", e.g., Home Depot (Ries and Ries, 2004). To test the gender influence on retailer brand equity, this study focuses on hypermarkets.

\section{Sample And Data Collection}

Shoppers were surveyed at the four major hypermarkets - Carrefour, R-T Mart, Costco, Géant - in Kaohsiung, Taiwan, the second largest city in the country. The sampling frame was an estimated proportion to the respective $(35 \%, 30 \%, 25 \%, 10 \%)$ market share of weekday and weekend shoppers who were at least 18 years old. The questionnaire included the researcher-developed 9 question demographic section. Second, a 23-item instrument developed by Pappu and Quester (2006) that was used in their customer-based brand equity (CBBE) study of specialty and department stores. The CBBE section items were measured by a 7-point Likert-type scale $(1=$ Strongly Disagree to 7 = Strongly Agree).

The sample includes 435 participants having the proportional respondents by gender. Males $(n=219)$ and females $(n=216)$ are equally represented with $60 \%$ being married and about $70 \%$ between 25 and 44 years old. Of the participants, more females $(n=92)$ than males $(n=72)$ were college graduates while more men $(n=91)$ than women $(n=75)$ were high school graduates. Almost $50 \%$ of the shoppers were sales, technicians, and clerical workers with many more males $(n=124)$ than females $(n=82)$ in these occupations. However, $60 \%$ of the participants earned between US $\$ 641$ and US $\$ 1,600$ monthly with females having higher income, e.g., 103 women and only 38 men earned between US\$1,121 and US\$1,600. Shopping purchases were generally balanced among men and women with $65 \%$ spending between US\$16.00 and US $\$ 80.00$ per visit. The vast majority (over $90 \%$ ) had shopped at the hypermarket. But females $(n=159)$ as compared to males $(n=138)$ shopped less often than once a week. Table 1 reports the participant profiles and shopping characteristics.

\section{Analytical Procedures}

Of the 23-item brand equity instrument, there were 4 brand loyalty items, 4 brand awareness, 5 perceived quality, and 10 brand association questions (Pappu and Quester, 2006). Varimax rotations with Kaiser-Meyer-Olkin criterion (eigenvalue greater than 1.0) were used to examine construct validity and to extract items. Two brand awareness items were regrouped to brand loyalty. One brand awareness item became brand association. Lastly, three brand association items were regrouped as brand awareness. Therefore, brand loyalty includes 6 items, brand awareness 4 items, brand association 8 items, and the 5 original perceived quality items remain unchanged. These constructs were tested for reliability using Cronbach's alpha scores and all easily exceeded the minimum of 0.70 (Hair, Anderson, Tatham, and Black, 1998) with a range from 0.843 to 0.942. 
Table 1: Hypermarket Shopper Profile by Gender

\begin{tabular}{|c|c|c|c|c|c|c|}
\hline \multirow[t]{2}{*}{ Shopper Characteristics } & \multicolumn{2}{|c|}{ Male Shopper } & \multicolumn{2}{|c|}{ Female Shopper } & \multicolumn{2}{|l|}{ Total } \\
\hline & No. & $\%$ & No. & $\%$ & No. & $\%$ \\
\hline Total & 219 & 50.3 & 216 & 49.7 & 435 & 100.0 \\
\hline \multicolumn{7}{|l|}{ Age } \\
\hline $18-24$ & 25 & 11.4 & 19 & 8.8 & 44 & 10.1 \\
\hline $25-34$ & 73 & 33.4 & 101 & 46.7 & 174 & 40.1 \\
\hline $35-44$ & 69 & 31.5 & 63 & 29.2 & 132 & 30.3 \\
\hline $45-54$ & 30 & 13.7 & 21 & 9.7 & 51 & 11.7 \\
\hline 55 and Older & 22 & 10.0 & 12 & 5.6 & 34 & 7.8 \\
\hline \multicolumn{7}{|l|}{ Marital Status } \\
\hline Not Married & 87 & 39.7 & 85 & 39.4 & 172 & 39.5 \\
\hline Married & 132 & 60.3 & 131 & 60.6 & 263 & 60.5 \\
\hline \multicolumn{7}{|l|}{ Educational Level } \\
\hline College Graduate Degree & 10 & 4.6 & 16 & 7.4 & 26 & 6.0 \\
\hline College Undergraduate Degree & 72 & 32.9 & 92 & 42.6 & 164 & 37.7 \\
\hline Attended College (No Degree) & 22 & 10.0 & 15 & 6.9 & 37 & 8.5 \\
\hline High School Graduate & 91 & 41.6 & 75 & 34.7 & 166 & 38.1 \\
\hline Less Than High School Graduate & 24 & 10.9 & 18 & 8.4 & 42 & 9.7 \\
\hline \multicolumn{7}{|l|}{ Occupation } \\
\hline Corporate Executive \& Manager & 10 & 4.6 & 22 & 10.2 & 32 & 7.4 \\
\hline Administrative Personnel & 19 & 8.7 & 11 & 5.1 & 30 & 6.9 \\
\hline Sales, Technician, Clerical & 124 & 56.5 & 82 & 38.0 & 206 & 47.3 \\
\hline Skilled Labor & 17 & 7.8 & 70 & 32.3 & 87 & 20.0 \\
\hline Unskilled Labor & 49 & 22.4 & 31 & 14.4 & 80 & 18.4 \\
\hline \multicolumn{7}{|l|}{ Income (Monthly)* } \\
\hline US $\$ 640$ or Less & 53 & 24.2 & 19 & 8.8 & 72 & 16.6 \\
\hline US\$641-\$1,120 & 83 & 37.9 & 40 & 18.5 & 123 & 28.3 \\
\hline US\$1,121-\$1,600 & 38 & 17.4 & 103 & 47.6 & 141 & 32.4 \\
\hline US $\$ 1,601-\$ 2,080$ & 13 & 5.9 & 32 & 14.8 & 45 & 10.3 \\
\hline US $\$ 2,081-\$ 2,560$ & 17 & 7.8 & 12 & 5.6 & 29 & 6.7 \\
\hline US $\$ 2,561$ or More & 15 & 6.8 & 10 & 4.7 & 25 & 5.7 \\
\hline \multicolumn{7}{|l|}{ Avg. Purchase Amount (Per Visit)* } \\
\hline US $\$ 16.00$ or Less & 31 & 14.2 & 25 & 11.6 & 56 & 12.9 \\
\hline US\$16.01-\$48.00 & 76 & 34.6 & 80 & 37.0 & 156 & 35.8 \\
\hline US\$48.01-\$80.00 & 60 & 27.4 & 48 & 22.2 & 108 & 24.8 \\
\hline US\$80.01-\$112.00 & 24 & 11.0 & 28 & 13.0 & 52 & 12.0 \\
\hline US $\$ 112.01-\$ 144.00$ & 17 & 7.8 & 22 & 10.2 & 39 & 9.0 \\
\hline US\$144.01 or More & 11 & 5.0 & 13 & 6.0 & 24 & 5.5 \\
\hline \multicolumn{7}{|l|}{ Purchase Experience } \\
\hline Not Purchased at This Hypermkt. & 22 & 10.0 & 18 & 8.3 & 40 & 9.2 \\
\hline Purchased at This Hypermarket & 197 & 90.0 & 198 & 91.7 & 395 & 90.8 \\
\hline \multicolumn{7}{|l|}{ Hypermarket Shopping Frequency } \\
\hline Less Than Once Per Week & 138 & 63.0 & 159 & 73.6 & 297 & 68.3 \\
\hline 1 to 3 Times Per Week & 67 & 30.6 & 43 & 19.9 & 110 & 25.3 \\
\hline 4 or More Times Per week & 14 & 6.4 & 14 & 6.5 & 28 & 6.4 \\
\hline \multicolumn{7}{|l|}{ Shopper By Hypermarket } \\
\hline Carrefour & 80 & 36.5 & 75 & 34.8 & 155 & 35.6 \\
\hline RT-Mart & 57 & 26.0 & 69 & 31.9 & 126 & 29.0 \\
\hline Costco & 56 & 25.6 & 53 & 24.5 & 109 & 25.1 \\
\hline Géant & 26 & 11.9 & 19 & 8.8 & 45 & 10.3 \\
\hline
\end{tabular}

* Note: 1 NT (Taiwan Dollar) = US\$.032 at time of survey.

\section{RESULTS}

To test the four hypotheses, t-tests were performed for gender (males, females) and the dimensions of customer-based brand equity (brand loyalty, brand awareness, perceived quality, brand association), as well as total 
brand equity (all four dimensions). The mean scores for females were higher than males for the four dimensions and total brand equity. Only brand association was significant $(\mathrm{p}<0.05)$. However, total brand equity was significantly different $(\mathrm{p}<0.01)$ between men and women shoppers. The complete results are shown in Table 2.

While the purpose of this study is to conceptualize gender role in contributing to brand equity, the intent also was to draw comparisons between four major hypermarkets. Therefore, the sampling frame has proportionate respondents to each hypermarket's estimated market share, e.g., Carrefour (35\%), R-T Mart (30\%), Costco (25\%), Géant (10\%). The goal was to compare gender, brand equity, and market share. These links might better explain successful "male friendly" and "female friendly" stores. For this, we used significantly different $(p<0.05)$ and similarity $(p>0.70)$ criterion. Table 3 presents the results of male and female participants by hypermarket.

The two market leaders, Carrefour and R-T Mart, have brand loyalty and perceived quality similarities ( $\mathrm{p}$ > 0.70 ) between men and women shoppers. Furthermore, only Carrefour of the four major hypermarkets has similarity for total brand equity. For all hypermarkets and the four dimensions (and total brand equity), Carrefour male shopper brand awareness was higher, but not significant $(\mathrm{p}<0.05)$, than females. Carrefour, also, was the only store that shows any significance (differences or similarities) for total brand equity $(\mathrm{p}>0.70)$. However, female shoppers at Géant have significantly higher $(\mathrm{p}<0.05)$ brand association than males.

Table 2: T-test Results for Customer-Based Brand Equity

\begin{tabular}{llll}
\hline Brand Equity Dimension & $\begin{array}{l}\text { Mean For } \\
\text { Male Shopper }\end{array}$ & $\begin{array}{l}\text { Mean For } \\
\text { Female Shopper }\end{array}$ & $\begin{array}{l}\text { Mean } \\
\text { Differences }\end{array}$ \\
\hline Brand Loyalty & 3.94 & 4.10 & 0.16 \\
Brand Awareness & 4.92 & 5.09 & 0.17 \\
Perceived Quality & 4.23 & 4.34 & 0.11 \\
Brand Association & 4.52 & 4.82 & $0.30^{* *}$ \\
Total Brand Equity & 4.37 & 4.58 & $0.21^{*}$ \\
\hline
\end{tabular}

Note: $*<0.05$

$* *<0.01$

To further analyze the comparative relationships between gender and customer-based brand equity, each item was evaluated by t-tests. The findings are reported in Table 4 . The mean scores for every item are higher for female shoppers than males. Brand association results revealed significant differences for four of the eight items. Females were more likely $(\mathrm{p}<0.001)$ than males to recognize that hypermarket from all others. Furthermore, females more likely believed than males that hypermarket offered (1) more value for money spent $(\mathrm{p}<0.01),(2)$ very good variety of products $(\mathrm{p}<0.01)$, and $(3)$ very good after-sale service $(\mathrm{p}<0.05)$. While not significant, females did rate their own hypermarket higher than males for the other brand association items, e.g., conveniently located, good store atmosphere, convenient facilities, in-store customer service. No other item for the remaining three brand equity dimensions shows a significant difference. However, perceived quality findings are of interest to this study. The perceived consistent products quality is very similar ( $p>0.70)$ between male and female shoppers. Yet none of the other items, e.g., good quality products, products durability, products reliability and products features, shows any significance (differences or similarities). 
Table 3 T-test Results for Customer-Based Brand Equity by Hypermarket

\begin{tabular}{lccc}
\hline Brand Equity Dimension & $\begin{array}{l}\text { Mean For } \\
\text { Male Shopper }\end{array}$ & $\begin{array}{l}\text { Mean For } \\
\text { Female Shopper }\end{array}$ & $\begin{array}{l}\text { Mean } \\
\text { Differences }\end{array}$ \\
\hline Carrefour & & & $0.05^{* *}$ \\
Brand Loyalty & 4.04 & 4.09 & 0.12 \\
Brand Awareness & 5.28 & 5.16 & $0.00^{* *}$ \\
Perceived Quality & 4.10 & 4.10 & 0.09 \\
Brand Association & 4.76 & 4.85 & $0.02^{* *}$ \\
Total Brand Equity & 4.52 & 4.54 & $0.08^{* *}$ \\
R-T Mart & & & 0.24 \\
Brand Loyalty & 3.87 & 3.95 & $0.05^{* *}$ \\
Brand Awareness & 4.79 & 5.03 & 0.35 \\
Perceived Quality & 4.13 & 4.18 & 0.20 \\
Brand Association & 4.38 & 4.73 & 0.26 \\
Total Brand Equity & 4.26 & 4.46 & 0.30 \\
Costco & & & 0.27 \\
Brand Loyalty & 4.21 & 4.47 & 0.36 \\
Brand Awareness & 4.97 & 5.27 & 0.30 \\
Perceived Quality & 4.71 & 4.98 & 0.50 \\
Brand Association & 4.66 & 5.02 & 0.55 \\
Total Brand Equity & 4.61 & 4.91 & 0.28 \\
Géant & & & $0.72^{*}$ \\
Brand Loyalty & 3.18 & 3.68 & 0.54 \\
Brand Awareness & 3.95 & 4.50 & \\
Perceived Quality & 3.81 & 4.09 & \\
Brand Association & 3.79 & 4.51 & \\
Total Brand Equity & 3.66 & & \\
\hline Note: & & & \\
\end{tabular}

Note: $*<0.05$

$* *>0.70$

\section{DISCUSSION}

As Ries and Ries (2004) observed, and as Home Depot acted (Waters, 2007), gender appears to have an influence on brand equity. There are "male friendly" and "female friendly" "big box" stores. Particular sets of relationships occur between the four construct measures - loyalty, awareness, perceived quality, association - of customer-based brand equity (CBBE) for male and female shoppers.

Hypothesis 1 expects males to have higher brand loyalty. The literature supports that males are loyal based on product performance and females only if service performance is acceptable (Moutinho and Goode, 1995). The results of this study find little support for $\mathrm{H}_{1}$. The brand loyalty dimension is not significant in the t-test (Table 2) or any of its six items (Table 4). But this study does find females believe that their hypermarket offers "very good after sales service" (brand association - Table 4) which suggests increased female brand loyalty. Thus, if "service" was not significantly higher for women in this study, female brand loyalty could have been lower. However, the market leaders, Carrefour and R-T Mart, have similar brand loyal male and female shoppers $(p>0.70)$ with slightly higher mean scores (loyalty) for females (Table 3). With these exceptions, there is no significant difference or similarity between male and female shopper brand loyalty.

Hypothesis 2 indicates females have higher brand awareness. The literature finds males use heuristic, schematic memory processing strategies while females use effortful, detailed elaboration strategies (Meyers-Levy, 1989; Meyers-Levy and Maheswaran, 1991) that may lead to females having greater awareness of brand alternatives. The results from this study do not support $\mathrm{H}_{2}$. Of all the mean scores, female brand awareness was the highest for the four brand equity dimensions (Table 2). Interesting for each of the four hypermarkets (Table 3), Carrefour male shoppers were the only one that had a (slightly) higher mean score, but not significant $(\mathrm{p}<0.05)$. Otherwise, female shoppers had higher mean scores with no significances (differences or similarities). 
Table 4: T-test Results for Customer-Based Brand Equity by Question

\begin{tabular}{|c|c|c|c|}
\hline Brand Equity Dimension & $\begin{array}{l}\text { Mean For } \\
\text { Male Shopper } \\
\end{array}$ & $\begin{array}{l}\text { Mean For } \\
\text { Female Shopper }\end{array}$ & $\begin{array}{l}\text { Mean } \\
\text { Differences } \\
\end{array}$ \\
\hline \multicolumn{4}{|l|}{ Brand Loyalty } \\
\hline Preferred choice & 4.10 & 4.29 & 0.19 \\
\hline Loyal to (hypermarket) stores & 3.98 & 4.05 & 0.07 \\
\hline Will not buy products from other & 3.67 & 3.86 & 0.19 \\
\hline My first choice & 3.73 & 3.87 & 0.14 \\
\hline Character. come to mind quickly & 4.13 & 4.31 & 0.18 \\
\hline Aware of (hypermarket) stores & 4.00 & 4.23 & 0.23 \\
\hline \multicolumn{4}{|l|}{ Brand Awareness } \\
\hline Have shopped at (hypermarket) & 5.51 & 5.66 & 0.15 \\
\hline Like (hypermarket) stores & 4.75 & 4.92 & 0.17 \\
\hline Feel proud to shop at stores & 4.72 & 4.93 & 0.21 \\
\hline Trust (hypermarket) for products & 4.70 & 4.83 & 0.13 \\
\hline \multicolumn{4}{|l|}{ Perceived Quality } \\
\hline Offer very good quality & 4.40 & 4.52 & 0.12 \\
\hline Offer consistent quality products & 4.35 & 4.39 & $0.04 * * * *$ \\
\hline Offer very durable products & 4.11 & 4.28 & 0.17 \\
\hline Offer very reliable products & 4.26 & 4.33 & 0.07 \\
\hline Offer prod with excellent features & 4.03 & 4.19 & 0.16 \\
\hline \multicolumn{4}{|l|}{ Brand Association } \\
\hline Stores are conveniently located & 4.53 & 4.76 & 0.23 \\
\hline Offers value for money & 4.28 & 4.61 & $0.33 * *$ \\
\hline Offers very good atmosphere & 4.53 & 4.75 & 0.22 \\
\hline Offer very convenient facilities & 4.57 & 4.76 & 0.19 \\
\hline Offer very good customer service & 4.52 & 4.74 & 0.22 \\
\hline Offer very good variety of prods. & 4.61 & 4.93 & $0.32 * *$ \\
\hline Offer very good after sls. service & 4.46 & 4.77 & $0.31 *$ \\
\hline Recognize among other stores & 4.67 & 5.26 & $0.59 * * *$ \\
\hline Total Brand Equity & 100.60 & 105.25 & $4.65 *$ \\
\hline \multirow{4}{*}{$\begin{array}{ll}* * & <0.01 \\
* * * & <0.001 \\
* * * * & >0.70\end{array}$} & & & \\
\hline & & & \\
\hline & & & \\
\hline & & & \\
\hline
\end{tabular}

Hypothesis 3 suggests females perceive higher quality. Perceived quality may be based on cues, e.g., brand name, price (Lichtenstein and Burton, 1989; Rao and Monroe, 1989), advertising (Kirmani and Wright, 1989). Women have lower threshold for (great exposure to) message cues elaboration (Meyers-Levy and Sternthal, 1991) that supports this hypothesis. However, this study generally finds otherwise in which $\mathrm{H}_{3}$ is not supported. Perceived quality was not significant (Table 2). Moreover, perceived quality shows some level of likeness between male and female shoppers. From the item analysis, the store offers "consistent quality products" (Table 4) was closely related based on mean scores. For market share leaders, Carrefour and R-T Mart, men and women shoppers have similar perception of the store's quality. Therefore, there may be a direct relationship between market share leadership and similarities of both gender's brand loyalty and perceived quality (Table 3 ).

Hypothesis 4 states females have higher brand association. The literature has two indications - brand personality (Aaker, 1997) favoring males and relationships (Fourier, 1998) favoring females. From this study, brand association was generally significant and favoring females, hence supports $\mathrm{H}_{4}$. Brand association was significant $(\mathrm{p}$ $<0.01$ ) (Table 2). Furthermore, four of the eight brand association items were significant - "very good after sales service" ( $p<0.05)$, "value for money" ( $p<0.01)$, "very good variety of products" $(\mathrm{p}<0.01)$, and "recognize among other stores" ( $p<0.001)$ (Table 4). However, the last of the four hypermarkets in market share was the only one (Géant) with female shopper's having a significantly higher brand association $(\mathrm{p}<0.05)$ (Table 3). Unlike brand 
loyalty and perceived quality (similarities), gender brand association (differences) may contribute little to market share position.

Total brand equity was not hypothesized. However, this is included for analysis and discussion. Total brand equity was significant $(\mathrm{p}<0.05)$ (Table 2). Interesting is that as the mean differences increase between male and female shopper total brand equity, the lower the market share. For example, Carrefour, the market leader, has a difference of only 0.02 mean scores between men (4.52) and women (4.54) that is very similar ( $p>0.70)$ (Table 3 ). Furthermore, this mean difference relationship continues, but without significance (differences or similarities), with the second highest market share position - R-T Mart (0.20), third position - Costco (0.30), and fourth position Géant (0.54).

\section{CONCLUSIONS}

"Genders friendly" hypermarkets seem more important than to be "male friendly" or "female friendly". Certain drivers appear to create brand equity and market position. The market share leaders - Carrefour (35\%) and R-T Mart (30\%) - have two (brand loyalty and perceived quality) of the four brand equity dimensions that are very similar between male and female shoppers $(\mathrm{p}>0.70)$. Moreover, Carrefour is the only hypermarket that has a highly similar $(p>0.70)$ total brand equity between the genders. Furthermore, the hypermarket with the lowest market share - Géant $(10 \%)$ - has the only brand equity dimension (brand association) that is significantly different $(\mathrm{p}<$ $0.05)$.

Costco results show no significance (differences or similarities) for any of the brand dimensions and total brand equity. However, Costco shoppers rated the hypermarket extremely high in all areas. For example, the mean scores for all dimensions and total brand equity were the highest for female shoppers as compared to the other three hypermarkets. In addition, male shopper mean scores were the highest in two dimensions (brand loyalty and perceived quality) and total brand equity, and second highest (to Carrefour) in the other two dimensions (brand awareness and brand association).

This study has certain limitations. While the study was conducted in the second largest city in Taiwan, Kaohsiung city, the findings cannot be generalized to other Asian or international markets. Hypermarkets are just one classification, general merchandise stores, of "big box" stores. Findings, therefore, are limited to this retail format.

While certain findings were determined, they lead to further identified research areas. Is Carrefour market leadership the result of customer-based brand equity? Or, is customer-based brand equity the result of market share? Would the same results be found for hypermarkets in different Asian markets? Or in the North American (or European) market? Is the Home Depot decision to develop Home Depot Design Centers the best retail branding strategy? Or would it be better served if Home Depot was more "genders friendly"? Would the results be similar with other mega-retailers and "category killers", e.g., Staples, Office Depot, Office Max? What has caused Costco to have high mean scores from both male and female shoppers but not significantly contributing to customer-based brand equity? Could this be determined by the understanding of its marketing strategy, e.g., marketing mix?

Therefore, are there significant differences between gender perceptions of retail stores that influence greater brand equity? With particular limitation, there are significant differences in Taiwan with females having higher hypermarket brand association and total brand equity.

\section{AUTHOR INFORMATION}

Hui-Chu Chen, Ph.D., is Assistant Professor in the College of Business Administration at TransWorld Institute of Technology, Yulin, Taiwan (R.O.C.). Prior to entering academe, Dr. Chen had a successful business career in Taiwan. She holds a Bachelor of Science in Business Administration (Management) and Master of Science (Economics) from Central Missouri State University (USA) and earned a Doctor of Philosophy (Corporate and 
Organizational Management) degree from Lynn University (USA). Dr. Chen has research interests in branding and consumer behavior.

Robert D. Green, D.B.A., is Professor of Marketing in the College of Business and Management at Lynn University, Boca Raton, Florida (USA). Prior to entering academe, Dr. Green had a successful 25-year business career in the United States. He has held faculty positions in the U.S. (Indiana State University) and internationally (United Arab Emirates and Ecuador). Dr. Green has had articles in Journal of Business \& Entrepreneurship, Global Business and Finance Review, and more than 40 other referred publications.

James Miller, Ph.D., is Professor of Management and Accounting in the College of Business and Management at Lynn University, Boca Raton, Florida (USA). Dr. Miller has had a successful classroom and administrative career. Students have recognized him numerous years as the "Outstanding Teacher." Dr. Miller has research interests in management and marketing in which he has been the recipient of a "Best Paper" Award. Dr. Miller also served as Dean for the College of Business and Management for 12 years.

\section{REFERENCES}

1. $\quad$ Aaker, David A. (1991). Managing Brand Equity. New York: The Free Press.

2. Aaker, David A. and Kevin Lane Keller (1990). Consumer Evaluations of Brand Extensions, Journal of Marketing, 54(January), 27-41.

3. Aaker, Jennifer (1997). Dimensions of Brand Equity, Journal of Marketing Research, 34(August), 347356.

4. Ailawadi, Kusum L. and Kevin Lane Keller (2004). Understanding Retail Branding: Conceptual Insights and Research Priorities, Journal of Retailing, 80(4), 331-342.

5. Arnold, Stephen J. and Monika Narang Luthra (2000). Market Entry Effects of Large Format Retailers: A Stakeholder Analysis, International Journal of Retailing \& Distribution, 28(4/5), 139-154.

6. Bendall-Lyon, Dawn and Thomas L. Powers (2002). The Impact of Gender Differences on Change in Satisfaction Over Time, Journal of Consumer Marketing, 19(1), 12-21.

7. Bettman, James R. (1979). Memory Factors in Consumer Choice: A Review, Journal of Marketing, 43(Spring), 37-53.

8. Boulding, William, Ajay Kalra, Richard Staelin, and Valarie Zeithaml (1993). A Dynamic Process Model of Service Quality: From Expectations to Behavior Intentions, Journal of Marketing Research, 30(February), 7-27.

9. $\quad$ Brokaw, Tom (2007). Boom!. New York: Random House Publishing.

10. Brown, Stephen (1990). The Wheel of Retailing: Past and Future, Journal of Retailing, 66(2), 143-149.

11. Chaudhuri, Arjun and Morris B. Holbrook (2001). The Chain of Effects from Brand Trust and Brand Effect to Brand Performance: The Role of Brand Loyalty, Journal of Marketing, 65(April), 81-93.

12. Darley, William K. and Robert E. Smith (1995). Gender Differences in Information Processing Strategies: An Empirical Test of the Selectivity Model in Advertising Response, Journal of Advertising, 24(1), 41-56.

13. Fournier, Susan (1998). Consumers and Their Brands: Developing Relationship Theory in Consumer Research, Journal of Consumer Research, 24(March), 343-373.

14. Hair, Jr., Joseph F., Rolph E. Anderson, Ronald L Tatham, and William C. Black (1998). Multivariate Data Analysis ( $5^{\text {th }}$ edition). Upper Saddle River, NJ: Prentice Hall.

15. Handlin, Amy (2007). Gender Opportunities to Enhance Direct-to-Consumer Advertising of GenderNeutral Pharmaceutical Brands: Factors Arising from Information Processing, Message Content and Demographic Change, The Business Review, Cambridge, 7(1), 33-37.

16. Hollander, Stanley C. (1960). The Wheel of Retailing, Journal of Marketing, 25(1), 37-42.

17. Homburg, Christian and Annette Giering (2001). Personal Characteristics as Moderators of the Relationship Between Customer Satisfaction and Loyalty, Psychology and Marketing, 18(1), 43-66.

18. Keller, Kevin Lane (1993). Conceptualizing, Measuring, and Managing Customer-Based Brand Equity, Journal of Marketing, 57(1), 1-22.

19. Keller, Kevin Lane (2003). Strategic Brand Management ( $2^{\text {nd }}$ ed.). Upper Saddle River, NJ: Prentice Hall. 
20. Kirmani, Amna and Peter Wright (1989). Money Talks: Perceived Advertising Expense and Expected Product Quality, Journal of Consumer Research, 16(December), 344-353.

21. Kotler, Philip and Kevin Lane Keller (2006). Marketing Management $\left(12^{\text {th }}\right.$ ed.). Upper Saddle River, NJ: Prentice Hall.

22. Lassar, Walfried, Banwanwari Mittal, and Arun Sharma (1995). Measuring Customer-Based Brand Equity, Journal of Consumer Marketing, 12(4), 11-19.

23. Lichtenstein, Donald L. and Scot Burton (1989). The Relationship Between Perceived and Objective PriceQuality, Journal of Marketing Research, 26(November), 429-443.

24. Lutz, Kathy A. and Richard J. Lutz (1977). Effects of Interactive Imagery on Learning: Application to Advertising, Journal of Applied Psychology, 62(4), 493-498.

25. McNair, Malcolm P. (1958). Significant Trends and Developments in the Postwar Period. In A.B. Smith (Ed.), Competitive Distribution in a Free, High-Level Economy and Its Implications for the University (pp. 1-25). Pittsburgh: University of Pittsburgh Press.

26. McNair, Malcolm P. and Eleanor G. May (1978). The Next Revolution of the Retailing Wheel, Harvard Business Review, 56(5), 81-91.

27. Meyers-Levy, Joan (1989). Gender Differences in Information Processing: A Selectivity Interpretation. In Patricia Cafferata and Alice M. Tybout (Eds.), Cognitive and Affective Responses to Advertising (pp. 219260). Lexington, MA: Lexington Press.

28. Meyers-Levy, Joan, Therese A. Louie and Mary T. Curren (1989). How Does the Congruity of Brand Names Affect Evaluations of Brand Name Extensions?, Journal of Applied Psychology, 79(1), 46-53.

29. Meyers-Levy, Joan and Durairaj Maheswaran (1991). Exploring Differences in Males' and Females' Processing Strategies, Journal of Consumer Research, 18(June), 63-70.

30. Meyers-Levy, Joan and Brain Sternthal (1991). Gender Differences in the Use of Message Cues and Judgments, Journal of Marketing Research, 28(1), 84-96.

31. Moutinho, Luiz and Mark Goode (1995). Gender Effects to the Formation of Overall Product Satisfaction: A Multivariate Approach, Journal of International Consumer Marketing, 8(1), 71-91.

32. Oliver, Richard L. (1980). A Cognitive Model of the Antecedents and Consequences of Satisfaction Decisions, Journal of Marketing Research, 17(4), 460-469.

33. Oliver, Richard L. (1999). Whence Consumer Loyalty, Journal of Marketing, 63(Special Issue), 33-44.

34. Pappu, Ravi and Ray W. Cooksey (2006). A Consumer-Based Method for Retail Equity Measurement: Results of an Empirical Study, Journal of Retailing and Consumer Services, 13(4), 317-329.

35. Pappu, R., P.G. Quester, and R.W. Cooksey (2005). Consumer-Based Brand Equity: Improving the Measurement-Empirical Evidence, Journal of Product and Brand Management, 14(2/3), 143-154.

36. Penn, Mark J. (2007). Microtrends. New York: Twelve.

37. Pride, William M. and O.C. Ferrell (2007). Foundations of Marketing ( ${ }^{\text {nd }}$ edition). Boston: Houghton Mifflin.

38. Rao, Akshay R. and Kent B. Monroe (1989). The Effect of Price, Brand Name, and Store Name on Buyers' Perceptions of Product Quality: An Integrative Review, Journal of Marketing Research, 26(August), 351357.

39. Ries, Al and Laura Ries (2004). The Origin of Brands. New York: HarperCollins Publishers.

40. Solomon, Michael R. (2007). Consumer Behavior $\left(7^{\text {th }}\right.$ ed.). Upper Saddle River, NJ: Prentice Hall.

41. The 100 Top Brands (2006), Business Week, (August 7), 60-66.

42. Wal-Mart Stores, Inc. The Wal-Mart Story, accessed January 17, 2008, http://walmartstores.com/GlobalWMStoresWeb/navigate.do?catg=5

43. Walsh, Gianfranco and Vincent-Wayne Mitchell (2005). Demographic Characteristics of Consumers Who Find It Difficult to Decide, Marketing Intelligence and Planning, 23(2/3), 281-295.

44. Waters, Jennifer (2007). Home Depot Targets Women. Wall Street Journal, (October 10), B5.

45. Yoo, Boonghee, Naveen Donthu, and Sungho Lee (2000). An Examination of Selected Marketing Mix Elements andBrand Equity, Journal of the Academy of Marketing Science, 28(2), 195-211.

46. Zeithaml, Valarie A. (1988). Consumer Perceptions of Price, Quality, and Value: A Means-End Model and Synthesis of Evidence, Journal of Marketing, 52(July), 2-22.

47. Zeithaml, Valarie A., Mary Jo Bittner, and Dwayne D. Gremler (2006). Services Marketing (4 ${ }^{\text {th }}$ ed.). New York: McGraw-Hill. 